\title{
Development Strategy in Bio-Geophysic Ecological Area of Mandeh Tourism to Meet Asean Economic Community (MEA)
}

\author{
Alexander Syam \\ Chairman (Rector) of STKIP Balai Selasa, Pesisir Selatan, Indonesia \\ Lecturer of Geography Department, STKIP Balai Selasa, Pesisir Selatan, Indonesia \\ Email: Alexandersyam093@gmail.com
}

\begin{abstract}
The purpose of this study is to determine and analyze Mandeh tourism development strategy and to formulate Development Alternatives using FGD (Focus Group Discussion) and AHP (Analytical Hierarchy Process). The type of this study is Mixed Method which is research that combines or integrates qualitative and quantitative Method to be used together in research activities in order to obtain more comprehensive, valid, reliable, and objective data. However, in this study is more weighted on qualitative research and quantitative data to support qualitative research. So, based on the results of FGD and AHP there are four main priorities strategy in dealing MEA: 1) tourism development of art, culture and religion, 2) tourism product's development of natural wonder, 3) development of underwater tourism, 4) providing socialization to meet MEA.
\end{abstract}

Keywords: Strategy, Development, Mandeh Tourism, MEA

\section{Introduction}

In 21 st century, internationalization of activities for almost all communities in the world will increase and lead to the development of inter-related symptoms among developing countries. Developments in technology and economic activity patterns are increasingly interconnected people to decide the fate of each other, and also compete with each other. This is particularly noticeable in the world of tourism activities as one of the main areas of economic activity in the world community. Because the international interact with each other in world trade will experience conflicts and controversies, the countries in the world require an agreement on certain rules in a global trading system. According to Mohammad Zamroni, many changes occur in the field of communication, starting from simple forms of communication to the electronic communication. Rapid changes, especially in the 20th century, by a number of experts are said as the revolution in many corners, ongoing business transactions, ranging from the preparation of Real Estate and Industrial Estate as well as investment in capital, establishment of production means, supply of raw materials, equipment and tools, product distribution and transportation by land, sea and air that coupled with the approval of insurance, commerce, communications, finance and so on.

There are four assumptions underlying the creation of a perfect competition in a particular market, one of them is: businessman cannot determine the price of products and services. To determine price in market is the equilibrium of supply and demand. Thus, businessman does not act as a price maker but only as a price taker. Goods or services that produced by businessman is indeed the same (product homogeneity). Businessman has freedom to enter or exit the market (perfect mobility of resources). Consumers and businessman have perfect information about it, such as: pReference, income level, cost as well as the technology used to produce goods and services. According Kit (2000), there are four objectives to be achieved by the application of community-based tourism concept, which are: 1) community-based tourism must contribute to improve and/or repair and conservation of natural or cultural resources, including 
biodiversity; 2) community-based tourism must contribute to local economic development thus increasing revenues and profits for the community; 3) community-based tourism should involve the participation of local communities; 4) community-based tourism has a responsibility to the tourists to provide products that maintain natural environment, social and cultural.

Community-based tourism should pay attention to the involvement of local communities is a prerequisite for achieving sustainable tourism development. The management should be done by local people whose lives and livelihood are affected by this development (Pitana, 2002), so that it will lead to a community-based management system as the main actors in tourism. Momentum MEA 2015 has been agreed by Indonesian Government that gives consequence to the nation of Indonesia as part of ASEAN to adapt and responsive in dealing with various forms of threats, challenges, and new opportunities through transforming ASEAN from an Association into ASEAN Community from an association into an ASEAN Community based on ASEAN Charter. Implementation of MEA started from 31 December 2015 (Benny Agus 2014). The population of Indonesia is very large compared to other ASEAN countries should be used as an opportunity rather than causing harm to domestic labor, a spectator entry of foreign workers and increasing the number of unemployed labor force. Therefore, Indonesia must be prepared to deal with MEA 2015 or ASEAN single market. The preparation of human resources both in terms of quality and in terms of the readiness of national law is needed. As a rule of law which is characterized by the law of welfare state, government plays an important role in protecting and ensuring the welfare of its people through policies that accommodate the interests of the people for the sake of people's welfare that people aspired. With the enactment of MEA in 2015, Indonesia must be ready to face a variety of challenges, both from a quality of readiness and preparation of human resources of national legal aspects to face global competition, especially the free flow of skilled labor.

The quality of human resources is paramount to be developed to improve the competitiveness of the nation to face global competition, especially MEA, 2015. According to Robert J. Eaton, 'CEO of Chrysler Corporation, United States: "The only way we can beat the competition is with people", Eaton confirms that in the midst of rapid technological sophistication, the role of HR in determining a company's success cannot be ignored, like the proverbial in human resources is a source of competitive advantage neither cracked by summer, nor weathered by rain. This is different from the technology products and production processes which are diminishing its value as a source of competition excellence. The success of marketing services is very dependence on human resources. One of the efforts that need to be done is to prepare a national policy that leads to the development and improvement of the quality of human resources of labor in preparing a skilled workforce that can compete with the skilled labor of other ASEAN member countries.

According to Sudana (2013), development of the concept of rural tourism is considered very effective in order to introduce and to give opportunities for - the amount for rural communities to understand the essence of the world of tourism as well as enjoy product of tourism. In the present context, management and utilization of islands in Indonesia become a challenge for Indonesian government. Where islands in Indonesia is currently in already made in reference for tourists to visit, one of which is the islands located in the province of West Sumatra. Sustainable nature tourism development has been taken into consideration in the management of natural resources, which is economic, social and aesthetic can be meet while maintaining the integrity. In the tourism system, there are many actors who play a role in the system. The actors are beings that exist in the various tourism sectors. In general, tourism agents are grouped into three main pillars, which are: (1) people, (2) private sector, and (3) government. Community in question is the general public that there are at destination, as the rightful owners of various resources and become tourism resources such as cultural tourism. Added to these communities are also public figures, intellectuals, NGOs, and media. Furthermore, the private group is an association of tourism enterprises and entrepreneurs, while the government is on different areas of the administration, from the central government, state, provincial, county, and so on (Pitana and Gayatri, 2005). 
In Act number 9 of 1990 about Tourism, Article 6 stated that one of the attractions is eco-tourism, in addition to cultural tourism and special interest tourism and in article 18 stated that concession object and appeal of ecotourism is a business resource utilization natural and environmental system to be used as a means of tourism. In addition, Director General Decree of PHPA No. 129 / Kpt / DJ / 1996 stated that ecotourism is an activity and most of the activities are voluntary and temporary and to enjoy the unique symptoms and the natural beauty of the conservation area. Both government policies confirmed that ecotourism is an activity that can give hope local communities to manage potential of natural surroundings. In addition, there are some scholars give the concept of ecotourism are: Fandeli (2000) to give the limits of ecotourism is a form of travel that is responsible for the preservation of the area's natural, economic benefits and maintain the cultural integrity of local society. Based on such understanding, the form of ecotourism is primarily a conservation movement that is made by a resident Meanwhile, the Organization of The Ecotourism Society (2000) says ecotourism a form of travel to natural areas that do with rules on environmental conservation and preservation of life and the welfare of local residents and Eplerwood (1999) ecotourism is the raw form of responsible travel and adventure in the natural areas that can create the tourism industry.

West Sumatra Province is one of the tourist destinations in Western Indonesia and is one of the 13 main entrance gates to the Indonesian tourism. In 2007 the Central Government set West Sumatra as featured local travel in western Indonesia with Bunaken and Biak in eastern Indonesia. Government of West Sumatra Province gives considerable attention to the development of tourism potential as demonstrated by the Vision Development of Tourism, Art and Culture of West Sumatra period 2006-2020, the "Realization of West Sumatra as Destinations Top Region Western Indonesia with Global Competitiveness and Environmental with Local Feature Indigenous, Religion, Nature and Culture ". In RIPPNAS, Mandeh Region declared a marine tourism development center for Western Indonesia. The area has several large and small islands as a potential object of tourist attraction of national and international. Geographically, this area has a bay, the sea relatively calm waters, and its rich coral reefs and mangrove vegetation. Mandeh and the surrounding region is located in the South Coastal District and the city of Padang, consisting of Kampung Carocok Tarusan, Mandeh, Nyalo River, Mudiak Aie, Sungai Pinang, which is part of the South Coastal District and Sungai Pisang located in the city of Padang. This area is approximately $61 \mathrm{~km}$ from the city of Padang and about 17 km from Painan.

Global tourism is growing very rapidly driven by the mass tourism. According Kodhyat (1992), mass tourism includes tourist arrivals in large quantities, come party for the sake of the group, and from different socioeconomic levels. Thought Kodhyat especially with regard to travelers in large quantities, clarified by Cooper (1993), citing the mind Cohen who divides rating mass into two types of rating the mass of organized (the organized mass tourist) and tourist masses of individuals (the individual mass tourist). Both types of travelers are still dependent on the existence of the existing tourism industry. Tourists visiting these islands generally come from Europe, America, and Australia, although still in limited amounts. The visit needs to be improved to consider the potential object of tourist attraction in Region Mandeh that can be developed is huge. To face global competition, especially the era of the ASEAN Economic Community, the necessary human resources and natural resources is superior and has the ability to compete with powerful competitors. Mandeh region is one of the flagship sites of immense charm to it within the ASEAN Economic Community (MEA) was prepared then it must be prepared tourism that could compete with other travel. To the authors are interested in doing research on "Development Strategy for Bio-Ecological Regions Travel Geophysics Mandeh Facing ASEAN Economic Community (MEA)"

\section{Method}

This study is a step of researchers by combining two forms of research is qualitative and quantitative research. In the opinion of Sugiyono (2013) mentioned that the combination of studies (Mixed 
Method) is the research that combine or merge between the Method of qualitative and quantitative Method to be used together in a research activity in order to obtain more comprehensive data, valid, reliable, and objective. But in this study is more weighted on the qualitative and quantitative data as supporting qualitative research. Primary data was collected by Field Survey (Data Field), conducting interviews with sources related to the condition of attraction Mandeh region. Secondary data were obtained BPS on population, Analysis Digitizing Map RTRW South Coastal District in 2013 Scale 1: 250.000 to see the location of accessibility BIM / Pier Tarusan Region Mandeh, Analysis Digitizing Map Area of Mandeh 2015 Scale 1: 250.000 to see Location Research Areas Mandeh and analysis Google earth to see objects Mandeh Tourism Region. The documents had been posted by relevant agencies. As for the research informants are local people, visitors, tourism agency, municipality, district and manager of attractions. Analysis of the data used is (Kelvin 2008) FGD (Focus Group Discussions) and (AHP (Analytical Hierarchy Process) to formulate Region Development Strategy Bio-Geophysics Ecology Tourism Mandeh Facing ASEAN Economic Community (MEA).

\section{Results and Discussion}

Bukit Mandeh attraction is one of the attractions that exist in the South Coast District of Koto XI Tarusan with approximately 8632 ha area. Kampung Mandeh is one of potential tourism, supported by the sight of the exotic beach travel is the main basis for the village Mandeh to rise into the marine tourism area in the island of Sumatra. Mandeh tourist area consists of a wide variety of tourist sites that have the potential to be developed for submission to investors, among others, Bukit Mandeh, Turkish Carocok, and Cubadak Island. Every tourist attraction area of Bukit Mandeh has characteristics as well as the attractiveness of each area.

Tourism Regions Mandeh located in the district of Koto XI Tarusan bounded directly to Padang city. This area is only $56 \mathrm{~km}$ from Padang that cover $\pm 18,000 \mathrm{Ha}$ land and takes about 56 minutes to reach it. This location is referred as Mandeh tourism areas because one of the villages in this region named Kampung Mandeh that famous in the middle of the bay Carocok Tarusan. Based on the interview with the Village Development Mandeh more emphasis on tourism travel, Art and Culture in the district/city with the approach of customs, culture and religion for the sake of regional cultural enlightenment and improvement of public welfare. To develop environmentally sound tourism products, relying on regional culture, cultural heritage and the natural wonder of local are adding value to global competitiveness. Based on the above map is colored Pink Wide Area Tourism Mandeh approximately 8632 ha. The area has several large and small islands as a potential object of tourist attraction of national and international. Geographically, this area has a bay, the sea relatively calm waters, and its rich coral reefs and mangrove vegetation while the small islands located in Region Mandeh among others:

Table 1. These small islands located in Region Mandeh

\begin{tabular}{|l|l|l|}
\hline No & Pulau & Luas \\
\hline 1 & Pulau Bintagor & 37 ha \\
2 & Pulau Padang & 32 ha \\
3 & Pulau Ular & 1 ha \\
4 & Pulau Marak & 256 ha \\
5 & Pulau Cubadak & 795 ha \\
6 & Pulau Taraju & 3 ha \\
7 & Pulau Setan Gadang & 1 ha \\
8 & Pulau Setan Kaciak & 1 ha \\
9 & Pulau Sironjong Kedi & 3 ha \\
10 & Pulau Sironjong Gadang & 25 ha \\
11 & Palau Nyamuak & 13 ha \\
\hline
\end{tabular}


Topography of Mandeh Region is undulated because of their considerable height differences between locations. In general, the western part of the area is low-lying with slope of 0-5\% due to its location adjacent to the beach and further to the east the higher slope. Conditions slope is dominated by a large slope of $40 \%$ (totaling $54.69 \%$ ). This area has a height above sea level ranges from 2 meters above sea level, 100 meters above sea level and 1000 meters above sea level. Flat area of land mostly located in the west (the coast) is generally in the form of a swamp where sago palm forest and mangrove forests. This land is used as settlements, agriculture and fisheries. Most Mandeh a protected forest area with slopes $>40 \%$ area of $+50 \%$ of the planning area. Tourism Regions Mandeh hill away from the city and the hilly roads lead to the difficulty the government provides adequate transportation facilities. The roads were damaged also found in many tourism areas at Bukit Mandeh. Access to some attractions not adequate, because the quality of infrastructure and transportation facilities are still limited availability and quality of facilities tourist accommodation is still limited, the promotion and marketing of tourism West Sumatra need to be increased, the negative perception of most people of West Sumatra on tourism, skilled human resources in the field tourism is relatively limited. Tourism activities that are already available in the Region Mandeh include: fishing, diving and snorkeling, camping, swimming and sunbeam, cross country, water-skiing and jet skiing, Panorama (sightseeing). To support the region in the face of MEA, there are some things that need to be noticed for Mandeh Tourism Travel for ASEAN Economic Community.

As there are several things that must be considered one of which is access to leading sites for more details can be seen on the map below. The purpose of the forum is to facilitate the location of tourist accessibility to attractions, where the red line is the road to the attractions of Pier breakwater Tarusan and the International Airport. With a total length of coastline as a whole in the Region Mandeh is $79.24 \mathrm{~km}$, consisting of $45.06 \mathrm{~km}$ along the Sumatra mainland and small islands with a length of approximately 34.18 km beaches. Geographically located at the position Mandeh Region 01011 '05 "South latitude, 1000 26' 55" East Longitude. Besides, the tourism potential presented by the Mount Mandeh among others while in Tarusan would soon be on the island Seronjong Tower there will be a tour snorkeling, Seronjong monkey jumping clip past the island Cubadak there will be diving and on the island of demons there will be Jet sky and dona boat and bathing at Tajun badarun waterfall.

Bukit tourism potential owned Mandeh if properly developed will be able to improve the economy and reduce poverty. Therefore, the Government of South Coastal District continues its efforts to develop the tourism sector this. Therefore, the development of the tourism sector will automatically move the wheels of the business associated therewith so as to create a multi double economic effect. Tourism growth is expected to result in employment growth, economic growth, and beneficial for the poor. All that would be achieved if the existing tourism potential in the South Coast dealt with seriously said by Head of Department of Tourism, Burhasman Bur, in the seminar Mandeh Bukit tourism profile. To develop sustainable tourism development under the community-based, the tourism sector must contain aspects of their community involvement and efforts to improve public participation. Tourism should be integrated in the socio-economic and cultural welfare of the wider community so that it can. The need for increased participation and empowerment of the dynamic towards the better, in terms of participation and empowerment is not just a benefit materially but also able to improve the human resources of local communities so that they can follow the development of tourism in the future, so that the management Tanah Lot, which is the cultural heritage can be preserved and sustainability can be enjoyed by future generations.

The number of visitors to travel Mandeh year after year continues to rise, if the number of travel continues to rise then Mandeh travel can become a mainstay of tourism, it is necessary readiness of the community. Based on that tourism Mandeh can already compete mounted ASEAN, the community and the government should be able to realize the challenges of the future, in the face of MEA Peoples, MEA are still many things to be prepared by the government and by the community of which improve the quality of human resources and human resources SDA Source natural resource which should be a lot of tourist areas Mandeh 
revamping one of them is transport and access to the area. According to interviews with the Department of Tourism Attraction of readiness Mandeh Facing the ASEAN Economic Community in 2017 to currently not ready for a lot of things that must be prepared to face (MEA). Where Mandeh Hill is famous for elegance and natural beauty but underneath it all the many constraints faced by Hill Mandeh. With this concept, the community became actors and object of tourism itself. While policies that can be taken the tourism industry to reduce the level of poverty, which can be done by employing the local community in the tourism business and encourages people to sell goods and services needed by tourism. Meanwhile, Head of Culture and Tourism said has the potential to become one of the mainstays of local revenue.

Various other tourism that potential to be developed, among others are paragliding and rock climbing. However, these development efforts need to consider various issues based on the FGD Focus Group Discussions to the District XI Tarusan Koto, Wali Nagari, Coastal Tourism Department and the local community. Based on discussions to prepare Mandeh travel in the face of the ASEAN Economic Community MEA is to do a variety of things as follows:

1) Development of tourism, art, culture and religion for the sake of regional cultural enlightenment and improvement of public welfare

2) Develop a tourism product, the natural charm of high added value and global competitiveness

3) Increasing public participation in the development of tourism

4) Develop human resource professionals to be able to think national and international level

5) Realize guarantees and legal certainty in the development of tourism

6) Developing science and technology in order to accelerate the development of tourism sector

7) Improving facilities and infrastructure as well as tourism management

8) Provide public education about the Utilization and profits ASEAN Economic Community

9) Increase sale

Based on the research findings can be formulated criteria for the Community in dealing MEA is Mandeh tourism development, improving facilities and infrastructure, and community empowerment. Assessment is done after discussion with respondents related to the research that the tourism department, district, village community leaders. Giving weight based on selection criteria formulated AHP Saaty (1993) in Ishizaka et al., (2009: 23). The values of relative comparison are processed by using Criterion Decision Plus.

After analyzing three criteria of the policy strategy Mandeh tourist areas in the face of the MEA policy alternatives are:

1) The tourism development of art, culture and religion (0.739)

2) Development of tourism products of natural wonder (0.759)

3) Development of underwater attractions (0.736)

4) Develop islands travel (0.654)

5) Improving land and sea transport equipment (0.627)

6) Build salinity and water (0.576)

7) Increase travel management (0.648)

8) Construction of the road to the attraction Mandeh (0.684)

9) The role of the community in the development of tourism (0.661)

10) Increase of human resources professionals $(0,568)$

11) Guarantee and certainty to the community (0.682)

12) Provide socialization to face the MEA (0.697)

Implementation strategy was designed based on the characteristics of each policy alternatives taking into account the physical, environmental, social, cultural and institutional. Efforts to implement the policy alternatives that can be reached with the cooperation of government, private sector civil society 
organizations/NGOs, academia and local communities. As a result of the implementation of policies detail consecutive based on the priority of the results of AHP is 1) The tourism development of art, culture and religion, 2) development of tourism products of natural charm, 3) Development of underwater travel, 4) Providing socialization to face the MEA.

\section{Conclusion}

Based on the analysis and consideration of the Development Strategy for Bio-Geophysics Ecological Regions Travel Mandeh to meet ASEAN Economic Community (MEA) that has been done in the area of Mandeh conclude that Mandeh tourism is able to compete on with other leading travel destinations. Judging from the geographical situation and natural beauty that is owned, but to face the ASEAN Economic Community MEA Mandeh tourist areas are still not ready. There are several factors that led to among other things, facilities and infrastructure such as access, transport, availability of salinity, which have not organized travel management and human resources are not yet ready to face the MEA. For that based on the results of FGD and AHP there are four main priorities strategy in dealing MEA: 1) The tourism development of art, culture and religion, 2) development of tourism products of natural wonder, 3) Development of underwater tours, 4) Providing socialization to face MEA.

\section{Reference}

Agus, B. (2014). Kajian Ekonomik Strategi Bangsa Indonesia Mencapai Keunggulan Bersaing Dalam Menyongsong Masyarakat Ekonomi Asean (MEA) 2015. Jurnal. PDP. Vol. 4. No 2

Anom, I. P. (2010). Analisis Pariwisata. Jurnal. Fakultas Pariwisata Universitas Udayana. Vol. 10. No.1

Bungin, B. (200)3. Analisis Data Penelitian Kualitatif. Jakarta: PT Raja Grafindo Perkasa.

Cooper, C., J. Flecher, D. Gilbert and S. Wainhill. (1993). Tourism Principle and Practice. London : Pitman Publishing.

Dewi, L. G. L. (2013). Usaha Pemberdayaan Ekonomi Masyarakat Desa Beraban dalam Pengelolaan Tanah Lot Secara Berkelanjutan. Jurnal Analisis Wisata, Vol. 13 No. 1 Th. 2013, Hal. 32.

Fandeli, C. (2000). Pengusahaan Ekowisata. Pustaka Pelajar, Yogyakarta.

Iskandar. (2008). Metodologi Penelitian Pendidikan dan Sosial (Kuantitatif dan Kualitatif). Jakarta : Gaung Persada Press.

Muhammad, F. (2014). Optimalisasi Kebijakan Ketenaga kerjaan Dalam Mempersiapkan Tenaga Kerja Terampil Menghadapi Masyarakat Ekonomi Asean 2015. Jurnal, Rechts Vinding Vol 2 No.2

Pendit, N. (1997). Ilmu Pariwisata Sebuah Pengantar Perdana. Jakarta:PT.Pradnya Paramita

Pitana. (2002). Apresiasi Kritis Terhadap Kepariwisataan Bali. Denpasar: PT. The Works.

Siswanto, H. (2012). Strategi Optimasi Wisata Massal di Kawasan Konservasi Taman Wisata Alam Grojongan Sewu. Jurnal Ilmu Lingkungan. Vol. 10: 100-110

Soetarso, P dan R. M. Mulyadin. (2001). Pembangunan Desa Wisata : Pelaksanaan Undang-Undang Otonomi Daerah. Info Sosial Ekonomi Vol 2 No 1.

Sudana, P. (2013). Strategi Pengembangan Desa Wisata Ekologis di Desa Belimbing, Kecamatan Pupuan Kabupaten Tabanan. Jurnal Analisis Wisata, Vol. 13 No. 1

Sugiyono. (2013). Metode Penelitian Kuantitaif kualitatif dan R \& D. Bandung: Alfabeta.

Syprianus, A. (2014). Peluang Industri dan Perdagangan Indonesia Dalam Pelaksanaan Masyarakat Ekonomi ASEAN. Jurnal, Rechts Vinding Vol 2 No.2

Zamroni, M. (2009). Perkembangan Teknologi Komunikasi dan Dampaknya Terhadap Kehidupan. Jurnal Dakwah, Vol. X No. 2.

\section{Alexander Syam}

Chairman (Rector) of STKIP Balai Selasa, Pesisir Selatan, Indonesia and Lecturer of Geography Department, STKIP Balai Selasa, Pesisir Selatan, Indonesia

Email: Alexandersyam093@gmail.com 